\title{
Immune Cell Induced Migration of Osteoprogenitor Cells Is Mediated by TGF- $\beta$ Dependent Upregulation of NOX4 and Activation of Focal Adhesion Kinase
}

\author{
Sabrina Ehnert ${ }^{1, *}(\mathbb{D})$, Caren Linnemann ${ }^{1}$, Romina H. Aspera-Werz ${ }^{1}$, Daria Bykova ${ }^{1}$, \\ Sara Biermann ${ }^{1}$, Leonie Fecht ${ }^{1}$, Peter M. De Zwart ${ }^{2}$, Andreas K. Nussler ${ }^{1}$ (I) \\ and Fabian Stuby 2 (1) \\ 1 Siegfried Weller Research Institute, Department of Trauma and Reconstructive Surgery, \\ Eberhard Karls University Tuebingen, BG Trauma Center Tuebingen, 72076 Tuebingen, Germany; \\ caren.linnemann@student.uni-tuebingen.de (C.L.); rominaaspera@hotmail.com (R.H.A.-W.); \\ daria.bykova@student.uni-tuebingen.de (D.B.); sarabiermann@web.de (S.B.); leonie.fecht@web.de (L.F.); \\ andreas.nuessler@gmail.com (A.K.N.) \\ 2 Department of Trauma and Reconstructive Surgery, Eberhard Karls University Tuebingen, \\ BG Trauma Center Tuebingen, 72076 Tuebingen, Germany; pdezwart@bgu-tuebingen.de (P.M.D.Z.); \\ fstuby@bgu-tuebingen.de (F.S.) \\ * Correspondence: sabrina.ehnert@med.uni-tuebingen.de or sabrina.ehnert@gmail.com; \\ Tel.: +49-7071-606-1065
}

Received: 27 June 2018; Accepted: 27 July 2018; Published: 31 July 2018

\begin{abstract}
The cytokines secreted by immune cells have a large impact on the tissue, surrounding a fracture, e.g., by attraction of osteoprogenitor cells. However, the underlying mechanisms are not yet fully understood. Thus, this study aims at investigating molecular mechanisms of the immune cell-mediated migration of immature primary human osteoblasts (phOBs), with transforming growth factor beta (TGF- $\beta$ ), nicotinamide adenine dinucleotide phosphate (NADPH) oxidase 4 (NOX4) and focal adhesion kinase (FAK) as possible regulators. Monocyte- and macrophage (THP-1 cells \pm phorbol 12-myristate 13-acetate (PMA) treatment)-conditioned media, other than the granulocyte-conditioned medium (HL-60 cells + dimethyl sulfoxide (DMSO) treatment), induce migration of phOBs. Monocyte- and macrophage (THP-1 cells)-conditioned media activate Smad3-dependent TGF- $\beta$ signaling in the phOBs. Stimulation with TGF- $\beta$ promotes migration of phOBs. Furthermore, TGF- $\beta$ treatment strongly induces NOX4 expression on both mRNA and protein levels. The associated reactive oxygen species (ROS) accumulation results in phosphorylation (Y397) of FAK. Blocking TGF- $\beta$ signaling, NOX4 activity and FAK signaling effectively inhibits the migration of phOBs towards TGF- $\beta$. In summary, our data suggest that monocytic- and macrophage-like cells induce migration of phOBs in a TGF- $\beta$-dependent manner, with TGF- $\beta$-dependent induction of NOX4, associated production of ROS and resulting activation of FAK as key mediators.
\end{abstract}

Keywords: primary human osteoblasts (phOBs); migration; NADPH oxidase 4 (NOX4); focal adhesion kinase (FAK)

\section{Introduction}

In Germany, almost 30\% of all hospitalized patients suffer from musculoskeletal injuries or diseases. In case of fractures, up to 30\% of the patients show delayed fracture healing, of which every 6th fracture results in a non-union [1]. Their surgical revisions cause approximately $15 \%$ of all therapeutic costs in Europe. Using the example of tibial fractures, Hak et al. reported that $82.8-93.3 \%$ of the costs to treat tibia fractures in Europe can be attributed to the treatment of non-unions [2], not 
considering the indirect costs, e.g., lack of salary due to lost-time injuries. Thus, delayed and impaired fracture healing represents major clinical and economic burden, and early diagnosis and intervention is desirable, which requires mechanisms that initiate fracture healing to be considered.

Immediately after trauma, the fracture gap is filled with blood and a hematoma is formed. In the following inflammatory phase, immune cells, e.g., monocytes, macrophages and granulocytes, infiltrate into the hematoma and start to digest the coagulated blood. The infiltration of immune cells into the fracture hematoma is pivotal for initiating the fracture healing, as these cells secrete factors that regulate the following recruitment, infiltration, proliferation and differentiation of cells involved in the formation of new bone [3-5]. Therefore, it is conceivable that circulating factors might be used to predict the success of fracture healing. A major immunomodulatory factor secreted by and acting on various immune cells is transforming growth factor beta (TGF- $\beta$ ) [6,7]. Zimmermann et al. proposed that an insufficient increase and a rapid decline in TGF- $\beta$ after the fracture may predict a non-union [8].

With an amount of $200 \mu \mathrm{g} / \mathrm{kg}$, TGF- $\beta$ is by far the most abundant cytokine in bone [9]. Osteoblasts and osteoclasts secrete TGF- $\beta$ in their latent form, which is then incorporated into the bone matrix $[10,11]$. Once released and activated during the bone turnover or fracture, active TGF- $\beta$ has been reported to critically regulate maintenance and expansion of mesenchymal stem/stromal cells, as well as the differentiation of osteoprogenitor cells [12-14], which express a large variety of high-affinity TGF- $\beta$ receptors [11]. Thus, many osteoblastic functions, e.g., chemoattraction, migration, proliferation, and collagen expression, are thought to be regulated by the canonical (often Smad3-dependent) TGF- $\beta$ signaling $[11,12]$.

In the TGF- $\beta$ superfamily, TGF- $\beta_{1}$ has the strongest chemotactic effect towards osteoblastic cells [15]. The underlying mechanisms, however, are not yet fully understood. Investigating vascular smooth muscle cells, NADPH oxidase 4 (NOX4) has been identified to critically regulate their migration. In these cells, Poldip2 associates with the subunit, p22phox, to activate NOX4 [16,17]. NOX4 belongs to the family of nicotinamide adenine dinucleotide phosphate (NADPH) oxidases, which is comprised of NOX1-5, DUOX 1, and DUOX2. The NADPH oxidases generate superoxide $\left(\mathrm{O}_{2}{ }^{-}\right)$from oxygen, using NADPH as an electron donor, thus representing the major sources of $\mathrm{O}_{2}{ }^{-}$in the human body [18]. In contrast to the other NADPH oxidases, NOX4 activity seems to be independent of cofactors and to directly correlate with its expression level [18]. However, often ubiquitously expressed NOX4 expression is regulated by many factors. In pulmonary artery smooth muscle cells and lung endothelial cells, NOX4 expression is reported to be induced by hypoxia in an HIF- $1 \alpha$-dependent manner $[19,20]$. In many other cell types, e.g., cardiac fibroblasts, hepatocytes, airway and artery smooth muscle cells, NOX4 expression is reported to be induced by TGF- $\beta$ in a Smad3-dependent manner $[18,21,22]$. The resulting increase in reactive oxygen species (ROS) is thought to regulate diverse cellular responses [20]. In migrating vascular smooth muscle cells, induction of NOX4 and ROS is associated with an activation of focal adhesion kinase (FAK) [23]. In migrating lung and breast epithelial cells, this phenomenon was reported to be dependent on p53 status [24], which in turn was tightly regulated by histone modifications [25]. These data indicate that NOX4 may be a key regulator of cell migration. The underlying mechanisms of cell migration, however, may vary between the different cell types.

As we wanted to gain better understanding of the migration of osteoprogenitor cells to a fracture site in response to the initial inflammation after fracture, we investigated the influence of immune cell conditioned medium (monocytic- and macrophage-like, and granulocytic) on migration and invasion of immature primary human osteoblasts (phOBs). Monocyte and macrophage conditioned media, which stimulated phOBs migration, and induced Smad3-dependent TGF- $\beta$ signaling in these cells. This in turn induced NOX4 expression and ROS formation. Blocking TGF- $\beta$ signaling, NOX4 activity, and FAK effectively reduced migration in phOBs. 


\section{Results}

\subsection{Leucocyte Conditioned Medium Stimulates Migration of phOBs}

Right after a fracture, immune cells were infiltrating into the fracture gap. They secrete factors that attract osteoprogenitor cells to the fracture gap. To simulate this process, in vitro leucocyte were isolated from human blood and cultured for $48 \mathrm{~h}$ to obtain a leucocyte-conditioned medium. This conditioned medium was added to phOBs cultures and migration was investigated by scratch assay (migration and proliferation). Addition of the leucocyte-conditioned medium supported gap closure (Figure 1a,b). Total DNA content revealed that the leucocyte-conditioned medium did not stimulate cell proliferation (Figure 1c).

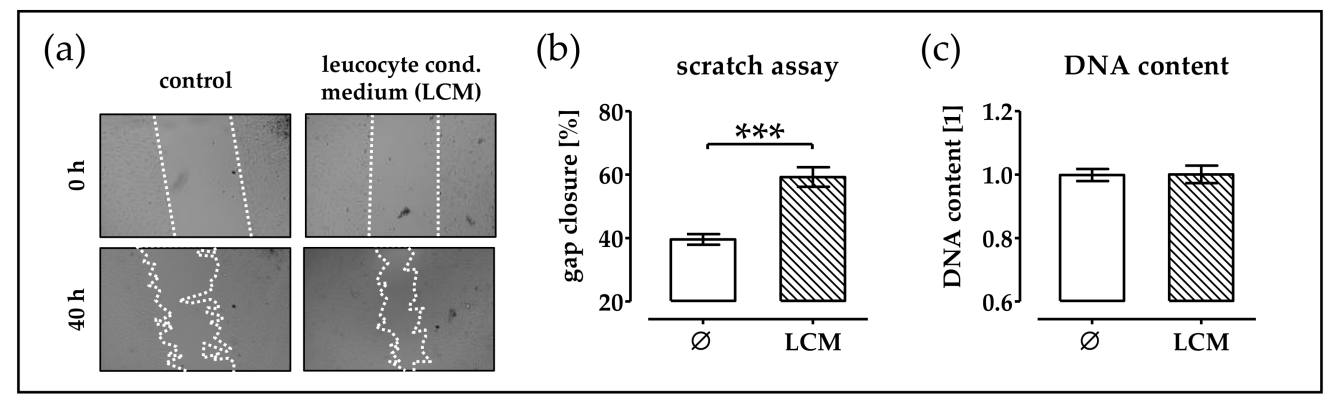

Figure 1. Leucocyte-conditioned medium (LCM) stimulates migration of primary human osteoblast (phOBs). In order to investigate the influence of LCM on phOBs $(N \geq 4, n \geq 4)$, migration scratch assays are performed in the presence or absence of LCM. (a) Representative microscopic images for the scratch assay (20× magnification). (b) Gap closure is determined from microscopic images (100 - gap $\operatorname{area}_{40 h} /$ gap area $_{0 \mathrm{~h}} \times 100$ ) with the help of the ImageJ software. (c) Total DNA content is measured with the help of Hoechst33342. Data are represented in bar diagrams (mean $\pm 95 \%$ C.I.). ${ }^{* * *} p<0.001$ as indicated.

\subsection{Monocytic Cells Stimulate Migration of phOBs}

Pappenheim staining showed that the isolated leucocytes contained both mono- and polymorph-nuclear cells. In order to investigate which cell type might be responsible for the observed effect of the LCM, we investigated the effects of immune cell-conditioned medium on the migration of phOBs. THP-1 suspension cells (representing monocytes), phorbol 12-myristate 13-acetate (PMA)-stimulated adherent THP-1 cells (representing macrophages), and dimethyl sulfoxide (DMSO)-challenged HL-60 cells (representing granulocytes) were kept in culture for $48 \mathrm{~h}[26,27]$. These conditioned media were added to the cultures of phOBs and migration was investigated by scratch assay (migration and proliferation, Figure 2a,b) under agar spot assay (chemotaxis, Figure 2c,d). Both assays revealed that the conditioned media from monocytic- and macrophage-like THP-1 cells ( \pm PMA stimulation) supported migration of phOBs, but the conditioned medium from granulocytic HL-60 cells did not. 


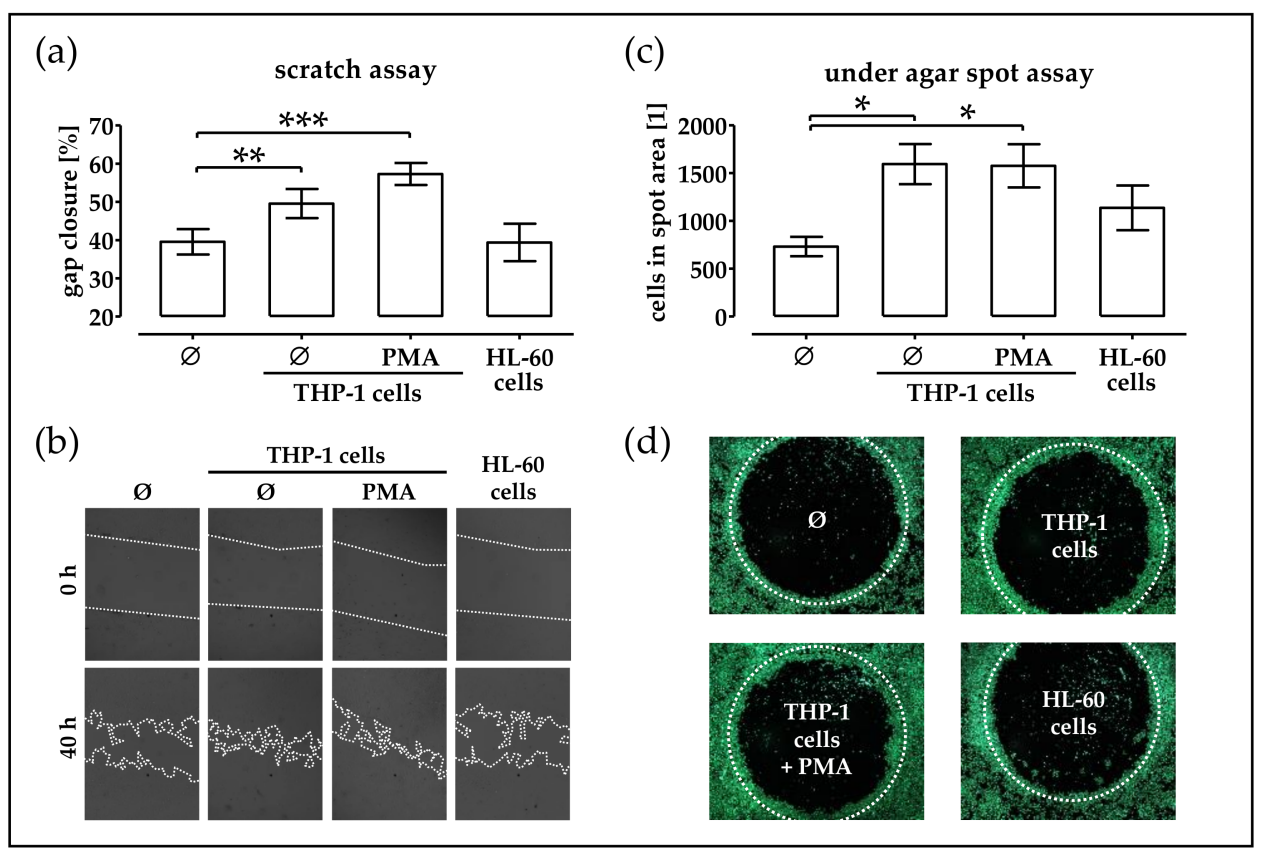

Figure 2. Conditioned medium from monocytic cells stimulates migration of phOBs. In order to investigate the influence of immune cell-conditioned medium on phOBs migration, a scratch assay and an under agar spot assay were performed. phOBs $(N \geq 4, n \geq 4)$ are stimulated with conditioned medium from THP-1 cells (representing monocytes), PMA-stimulated adherent THP-1 cells (representing macrophages), and DMSO-stimulated HL-60 cells (representing granulocytes). (a) For the scratch assay, gap closure was determined from microscopic images (100 - gap area $40 \mathrm{~h} / \mathrm{gap}$ area $_{0 \mathrm{~h}} \times 100$ ) with the help of the ImageJ software. (b) Representative microscopic images for the scratch assay (20× magnification). (c) For the under agar spot assay, the number of cells in the spot area was determined from microscopic images with the help of the ImageJ software. (d) Representative microscopic images for the under agar spot assay (12.5 $\times$ magnification). Cells were visualized with Calcein-AM stain for living cells. Data are represented in bar diagrams (mean $\pm 95 \%$ C.I.). ${ }^{*} p<0.05$, ** $p<0.01$, and ${ }^{* * *} p<0.001$ as indicated.

\subsection{Conditioned Medium from THP-1 Cells ( $(P M A)$ Activates TGF- $\beta$ Signaling in phOBs}

TGF- $\beta$ has been proposed as key chemokine for osteoprogenitor cells. Thus, as the immune cell-conditioned medium stimulated migration of phOBs, we wanted to check whether TGF- $\beta$ signaling was induced in these cells. Activation of TGF- $\beta$ signaling was assessed with the help of an adenoviral-based reporter (Ad5-CAGA9-MLP-Luc), which caused the production of a luciferase in the TGF- $\beta$ challenged cells. phOBs exposed to the conditioned medium from monocytic- and macrophage-like THP-1 cells ( \pm PMA stimulation) showed a clear induction of TGF- $\beta$ signaling, which phOBs exposed to the conditioned medium from granulocytic HL-60 cells did not exhibit (Figure 3a). A scratch assay revealed that addition of rhTGF- $\beta_{1}(5 \mathrm{ng} / \mathrm{mL})$ to the culture medium accelerated gap closure of phOBs (Figure $3 b, c)$. Similarly, the under agar spot assay confirmed the chemoattractive properties of rhTGF- $\beta_{1}$ (Figure $3 \mathrm{~d}$,e). 


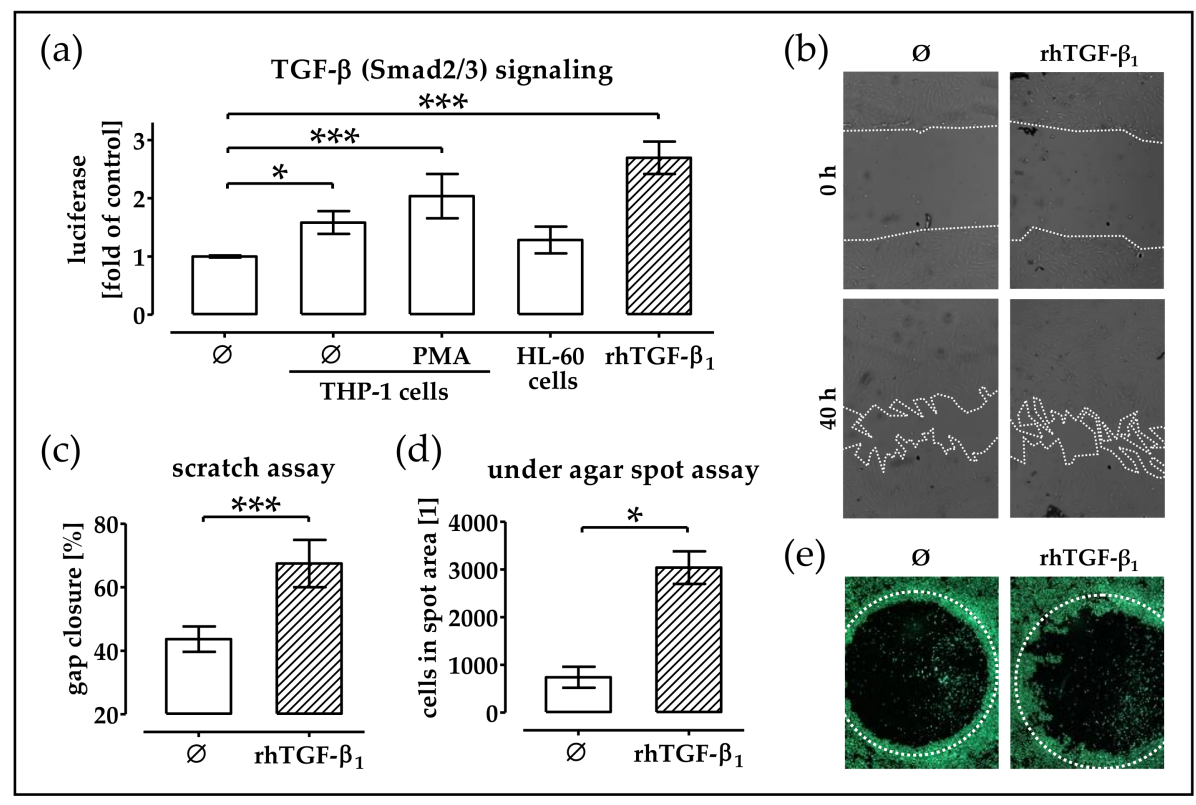

Figure 3. Conditioned medium from monocytic cells stimulates TGF- $\beta$ (Smad2/3) signaling in phOBs. (a) phOBs $(N=4, n=3)$, infected with the Smad3/4 reporter adenovirus (Ad5-CAGA9-MLP-Luc), were stimulated with conditioned medium from THP-1 cells (representing monocytes), phorbol 12-myristate 13-acetate (PMA)-stimulated adherent THP-1 cells (representing macrophages), and dimethyl sulfoxide (DMSO)-stimulated HL-60 cells (representing granulocytes). In the presence of active TGF- $\beta$ luciferase is expressed in the cytoplasm of the cells. After $48 \mathrm{~h}$, the luciferase activity was measured with a microplate reader. (b-e) In order to investigate the influence of rhTGF- $\beta_{1}(5 \mathrm{ng} / \mathrm{mL})$ on phOBs migration, a scratch assay and an under agar spot assay were performed. (b) Representative microscopic images for the scratch assay (20× magnification). (c) Gap closure was determined from microscopic

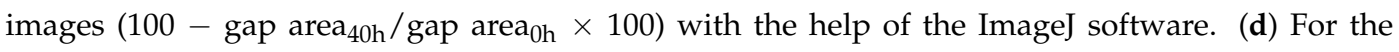
under agar spot assay, the number of cells in the spot area was determined from microscopic images with the help of the ImageJ software. (e) Representative microscopic images for the under agar spot assay (12.5 $\times$ magnification). Cells were visualized with Calcein-AM stain for living cells. Data are represented in bar diagrams (mean $\pm 95 \%$ C.I.). ${ }^{*} p<0.05$ and ${ }^{* * *} p<0.001$ as indicated.

\section{4. rhTGF- $\beta_{1}$ Treatment Increases Expression and Function of NOX4 in phOBs}

In order to investigate the effect of rhTGF- $\beta_{1}$ on the oxidative stress-related genes in phOBs, cells were cultured in an osteogenic medium in the presence or absence of $5 \mathrm{ng} / \mathrm{mL}$ rhTGF- $\beta_{1}$. After $48 \mathrm{~h}$, gene expression was screened with the help of the human $\mathrm{RT}^{2}$ Profiler PCR Array Oxidative Stress Plus. Expression of GPX3, CAT, FTH1, and NQO1 was approximately half as much as that in rhTGF- $\beta_{1}$ treated phOBs, compared to untreated phOBs. However, the strongest change in the gene expression was observed for NOX4. NOX4 expression was strongly (5.6-fold) induced by rhTGF- $\beta_{1}$ when compared to untreated cells (Figure $4 \mathrm{a}$ ). The effect of rhTGF- $\beta_{1}$ on NOX4 expression was confirmed by semi-quantitative RT-PCR. Therefore, phOBs were cultured for $48 \mathrm{~h}$ in the osteogenic medium in the presence or absence of $5 \mathrm{ng} / \mathrm{mL}$ rhTGF- $\beta_{1}$. Addition of $5 \mathrm{ng} / \mathrm{mL}$ rhTGF- $\beta_{1}$ significantly increased (2.7-fold $/ p<0.001 / \alpha=0.05$ ) NOX4 expression (Figure $4 \mathrm{~b}$ ). Similar results were observed on the protein level. rhTGF- $\beta_{1}$-treated phOBs $(48 \mathrm{~h}$ ) showed significantly increased $(2.2$-fold $/ p<0.01 / \alpha=0.05)$ NOX4 levels when compared to untreated cells (Figure 4c). In order to measure NOX4 activity, we detected ROS formation (its reaction product) in phOBs after 24-h osteogenic differentiation in the presence or absence of $5 \mathrm{ng} / \mathrm{mL}$ rhTGF- $\beta_{1}$. Upon addition of NADPH (substrate for NOX4), ROS production was significantly increased (1.9-fold $/ p<0.001 / \alpha=0.05)$, suggesting an increased NOX4 activity (Figure $4 \mathrm{~d})$. 


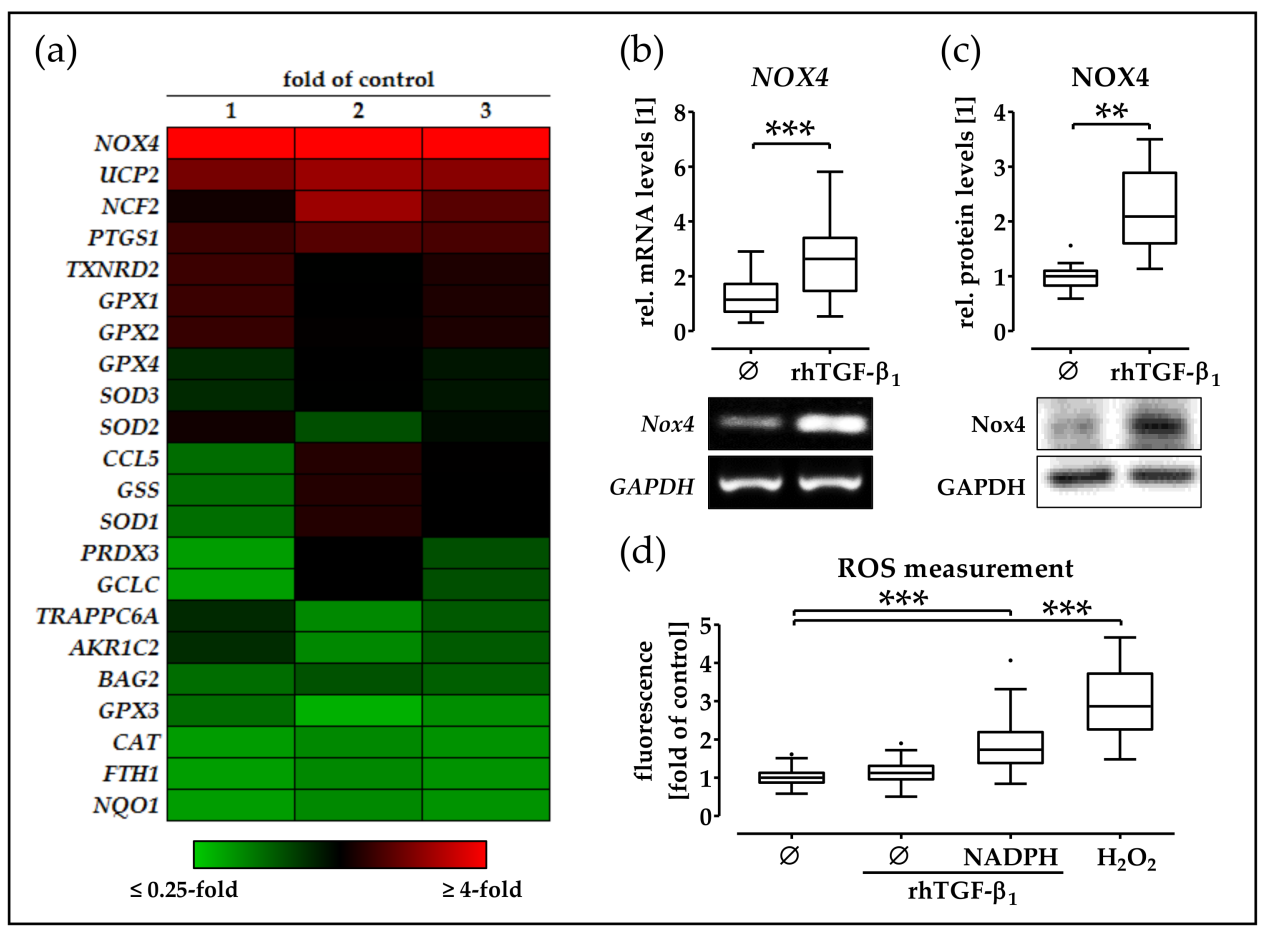

Figure 4. rhTGF- $\beta_{1}$ induces expression and activity of nicotinamide adenine dinucleotide phosphate (NADPH) oxidase 4 (NOX4) in phOBs. (a) Expression of oxidative stress-related genes was determined using the human $\mathrm{RT}^{2}$ Profiler PCR Array Oxidative Stress Plus (Qiagen, Hilden, Germany), in phOBs $(N=16 /$ pooled; $n=2)$ cultured in an osteogenic medium for $48 \mathrm{~h}$ in the presence or absence of $5 \mathrm{ng} / \mathrm{mL}$ rhTGF- $\beta_{1}$. Data are presented in heat map, showing relative expression levels in rhTGF- $\beta_{1}$-treated cells in comparison to untreated cells. To confirm the results, 9 individual donors $(N=9 ; n=2)$ are cultured in the osteogenic medium for $48 \mathrm{~h}$ in the presence or absence of $5 \mathrm{ng} / \mathrm{mL}$ rhTGF- $\beta_{1}$. (b) NOX4 mRNA levels were determined by semi-quantitative RT-PCR. (c) NOX4 protein levels are determined by Western blot. Band intensities were quantified using the ImageJ software. (d) NOX4 activity in cultured ( $48 \mathrm{~h} \pm 5 \mathrm{ng} / \mathrm{mL}$ rhTGF- $\left.\beta_{1}\right)$ phOBs $(N=6, n=4)$ was determined indirectly by measuring the formed ROS with the DCFH-DA assay. NADPH was added as a substrate for NOX4. $\mathrm{H}_{2} \mathrm{O}_{2}$ was used as a positive control. Data are represented in box blots (Box and Whiskers-Tukey to visualize outliers). ${ }^{* *} p<0.01$ and ${ }^{* * *} p<0.001$ as indicated.

\subsection{RhTGF- $\beta_{1}$ Induces NOX4 Expression Activates Focal Adhesion Kinase Signaling}

The work of Boudreau and colleagues reports that over-expression of NOX4 and the associated increase in ROS induce migration of tumor epithelial cells via activation of focal adhesion kinase signaling [28]. Thus, we wanted to investigate if a comparable mechanism holds for rhTGF- $\beta_{1}$-stimulated phOBs (for schematic overview, see Figure $5 a$ ). To block rhTGF- $\beta_{1}$ signaling, cells were co-incubated with the Alk5 inhibitor (Alk5i) SB431652, which effectively blocked rhTGF- $\beta_{1}$ signaling at a concentration as low as $5 \mathrm{nM}$ (Figure 5b). To block NOX4 activity, cells were co-incubated with Apocynin (NOX4i). Fifty micromolar Apocynin was sufficient to significantly reduce NOX4-dependent ROS production in rhTGF- $\beta_{1}$-treated phOBs (Figure $5 \mathrm{c}$ ). Western blot analysis confirmed the activation of TGF- $\beta$ signaling by rhTGF- $\beta_{1}$ shown by increased levels of phospho-Smad 3 . SB431652 (Alk5i)-treated cells showed no phosphorylation of Smad3. NOX4i (Apocynin) and FAKi (FAKi14) did not significantly affect phosphorylation of Smad3. Cells with the activated TGF- $\beta$ signaling showed increased levels of NOX4 and the activation of focal adhesion kinase signaling by increased levels of phospho-FAK (Y397). Cells solely treated with the FAKi (FAKi14) showed decreased levels of phospho-FAK (Y397), proving the effectiveness of the inhibitor (Figure 5d). 


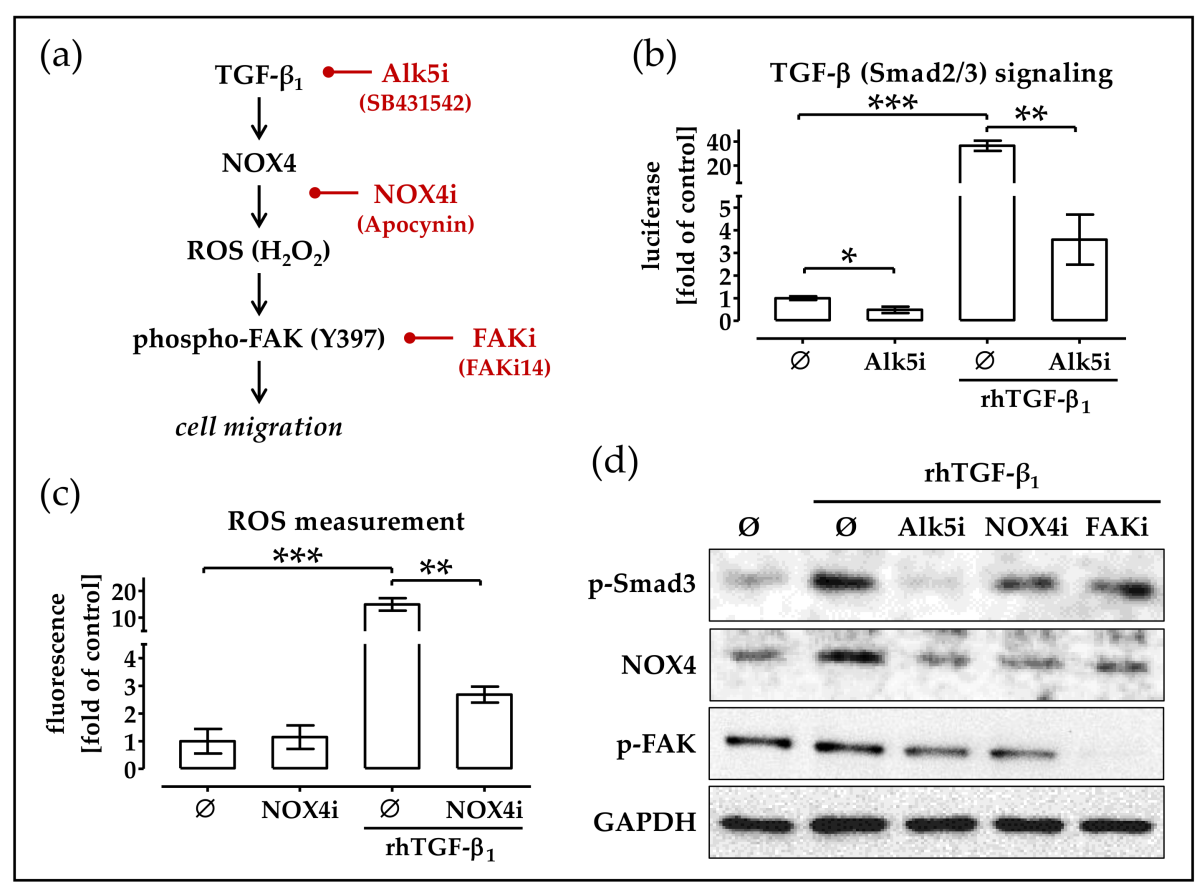

Figure 5. rhTGF- $\beta_{1}$-induced NOX4 expression activates focal adhesion kinase signaling. (a) Simplified overview on the proposed mechanism. (b) phOBs $(N=4, n=3)$, infected with the Smad3/4 reporter adenovirus (Ad5-CAGA9-MLP-Luc), were stimulated with $5 \mathrm{ng} / \mathrm{mL}$ rhTGF- $\beta_{1}$, leading to luciferase expression in the cells. Cells were additionally incubated with the Alk5 inhibitor (Alk5i/5 nM SB431542). After $48 \mathrm{~h}$, the luciferase activity was measured with a microplate reader. (c) NOX4 activity in cultured phOBs $\left(48 \mathrm{~h} \pm 5 \mathrm{ng} / \mathrm{mL}\right.$ rhTGF- $\left.\beta_{1}\right)(N=4, n=4)$ was determined indirectly by measuring the formed ROS with the DCFH-DA assay. To block NOX4 activity, cells were incubated with $50 \mu \mathrm{M}$ Apocynin (NOX4i). NADPH was added as a substrate for NOX4. (d) Representative Western blot images for phospho-Smad3, NOX4, phospho-FAK (Y397), and GAPDH levels in pooled samples of phOBs $(N=3)$ treated for $24 \mathrm{~h}$ with $\pm 5 \mathrm{ng} / \mathrm{mL} \mathrm{rhTGF}-\beta_{1}$ and the respective inhibitors for Alk5i ( $5 \mathrm{nM}$ SB431542), NOX4i (50 $\mu \mathrm{M}$ Apocynin), and FAKi (5 $\mu \mathrm{M}$ FAKi14). Data are represented in bar diagrams (mean $\pm 95 \%$ C.I.). ${ }^{*} p<0.05,{ }^{* *} p<0.01$, and ${ }^{* * *} p<0.001$ as indicated.

\subsection{Blocking TGF- $\beta$ Signaling, NOX4 Activity and FAK Activation Delays Migration of TGF- $\beta$ Treated phOBs}

To investigate the importance of the observed induction of NOX4 and subsequent activation of focal adhesion kinase for cell migration, a scratch assay was performed. As observed before, the gap closure was strongly accelerated in the presence of $5 \mathrm{ng} / \mathrm{mL}$ rhTGF- $\beta_{1}$. Blocking the TGF- $\beta$ signaling with the Alk5 inhibitor (Alk5i/SB431542) significantly slowed down the gap closure. Similarly, the inhibition of NOX4 activity with Apocynin (NOX4i) and blockage of focal adhesion kinase signaling with FAKi14 (FAKi) significantly slowed down the gap closure (Figure 6a,b). To further investigate rhTGF- $\beta_{1}$ chemoattraction, an under agar spot assay was performed. Upon addition of rhTGF- $\beta_{1}$ to the spot significantly more cells entered the spot area. Addition of the Alk5 inhibitor (Alk5i/SB431542) to the culture medium significantly reduced the migration. Addition of the NOX4 inhibitor (NOX4i), Apocynin, also slowed down the cells migration. Similarly, in the presence of the FAK inhibitor (FAKi), FAKi14, less cells entered the spot area (Figure 6c,d). In addition, a scratch assay with LCM and the respective inhibitors was performed. As before, addition of LCM favored gap closure. Simultaneous addition of the Alk5 inhibitor (Alk5i SB431542), the NOX4 inhibitor (NOX4i/Apocynin), and the FAK inhibitor (FAKi/FAKi14) slowed down the gap closure (Figure 6a/hatched bars). 


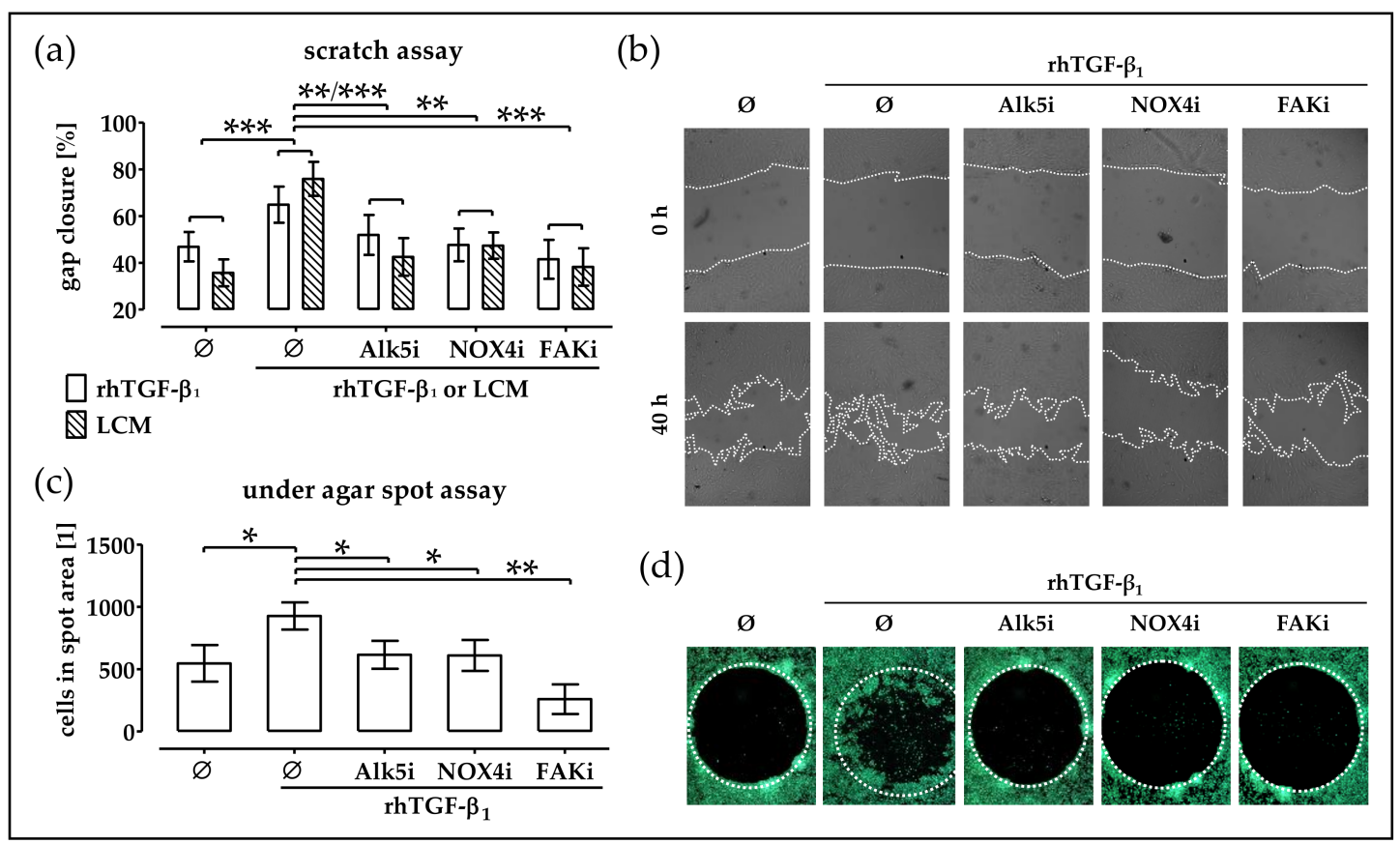

Figure 6. rhTGF- $\beta_{1}$ induces migration of phOBs via NOX4-dependent activation of focal adhesion kinase. The phOBs migration was investigated by scratch assay and under agar spot assay. phOBs ( $N \geq 4, n \geq 4$ ) were stimulated with $5 \mathrm{ng} / \mathrm{mL}$ rhTGF- $\beta_{1}$ or LCM (leucocyte conditioned medium) and the respective inhibitors for Alk5i (5 nM SB431542), NOX4i (50 $\mu$ M Apocynin), and FAKi (5 $\mu \mathrm{M}$ FAKi14). (a) For the scratch assay, the gap closure was determined from microscopic images (100 - gap area $_{40 \mathrm{~h}} /$ gap area $_{0 \mathrm{~h}} \times 100$ ) with the help of the ImageJ software. (b) Representative microscopic images for the scratch assay (20× magnification). (c) For the under agar spot assay, the number of cells in the spot area was determined from microscopic images with the help of the ImageJ software. (d) Representative microscopic images for the under agar spot assay (12.5 $\times$ magnification). Cells were visualized with Calcein-AM stain for living cells. Data are represented in bar diagrams (mean $\pm 95 \%$ C.I.). ${ }^{*} p<0.05,{ }^{* *} p<0.01$, and ${ }^{* * *} p<0.001$ as indicated.

\subsection{Basal NOX4 Levels Correlate with the Migration Potential of Osteogenic Cell Lines}

To emphasize the importance of NOX4 in cell migration, we investigated migration potential of the 3 different osteogenic cell lines-MG-63, Cal-72, and SaOs-2, in comparison to phOBs. Strongest basal migration was observed in Cal-72 cells. SaoS-2 cells showed a basal migration comparable to phOBs. Slowest migration was observed in MG-63 cells. In all investigated cells, the migration was favored by rhTGF- $\beta_{1}$ (Figure $7 \mathrm{a}, \mathrm{b}$ ).

To check the correlation of the cells migration capacity with the NOX4 expression levels, RT-PCR with the respective cell lines was performed. While basal NOX4 expression in MG-63 cells was close to the detection limit, SaOs-2 cells and phOBs expressed moderate levels of NOX4. Strongest basal NOX4 expression was observed in Cal-72 cells (Figure 7c). Comparing the NOX4 expression levels with the cells migration capacity revealed that both parameters correlated well $\left(R^{2}=0.7323\right)$ with each other (Figure 7d). 


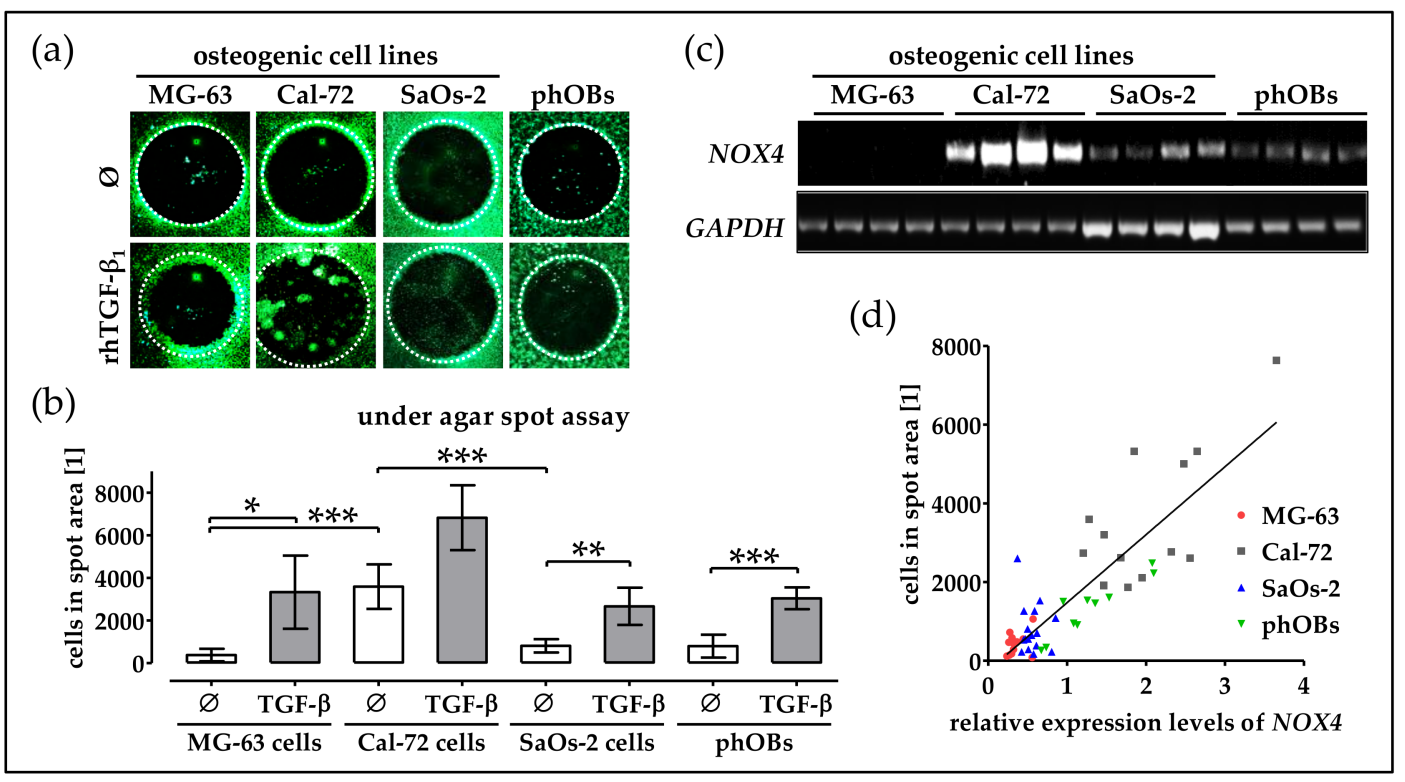

Figure 7. Migration of osteogenic cell lines and phOBs is inducible with rhTGF- $\beta_{1}$ and correlates with their NOX4 expression. Migration of osteogenic cell lines (MG-63, Cal-72 and SaOs-2) and phOBs was investigated by under agar spot assay $\left(N \geq 4, n \geq 4 / \pm 5 \mathrm{ng} / \mathrm{mL}\right.$ rhTGF- $\beta_{1}$. (a) Representative microscopic images for the under agar spot assay (12.5× magnification). (b) For the under agar spot assay, the number of cells in the spot area was determined from microscopic images with the help of the ImageJ software. Cells were visualized with Calcein-AM stain for living cells. (c) Basal NOX4 mRNA levels were determined by semi-quantitative RT-PCR. (d) Correlation of between the NOX4 expression levels and the migration capacity of the cells $\left(R^{2}=0.7323\right)$. Data are represented in bar diagrams (mean $\pm 95 \%$ C.I.). ${ }^{*} p<0.05,{ }^{* *} p<0.01$, and ${ }^{* * *} p<0.001$ as indicated.

\section{Discussion}

The present work aimed at identifying mechanisms that regulate migration of osteoprogenitor cells to a fracture site. A possible regulatory role of immune cells in this process has been discussed for years. The immune cells, infiltrating into the fracture gap, secrete factors that stimulate migration, proliferation and differentiation of osteoprogenitor cells [3-5]. Thus, the immune system plays a central role in tissue repair and regeneration, as it determines speed and outcome of the healing process [29]. Indeed, patients with both an over-activated and a suppressed immune systems frequently show delayed fracture healing [30].

It has been reported that the fracture hematoma develops an osteogenic potential within the first four days after a trauma. This osteogenic potential is strong enough to induce bone formation at ectopic sites upon explantation of the hematomas [31]. Similarly in our experiments, LCM stimulated migration of osteoprogenitor cells other than their proliferation. Granulocytes, monocytes and macrophages represent the first cells infiltrating into the fracture hematoma [32]. In the present work, we used unchallenged THP-1 cells to represent monocytes, PMA-stimulated THP-1 cells to represent macrophages, and DMSO-challenged HL-60 cells to represent granulocytes [26,27]. Interestingly, the monocyte- and macrophage-conditioned media, but not the granulocyte-conditioned medium, stimulated migration of phOBs. This is in line with the finding that depletion of neutrophils was not sufficient to delay fracture healing in a mouse model, but strongly affected the recruitment of monocytes and macrophages into the fracture hematoma [33]. This process is supposed to be mediated by granulocytic cytokines (e.g., IL-1, IL-6, IL-10, TNF- $\alpha$, MCP-1, CXCL-1 $\alpha$, MIP-1) that attract monocytes and regulate their differentiation to macrophages [33-35]. Although THP-1 cells and HL-60 cells are the most well described representatives for monocyte/macrophage or granulocytes cell lines, their response might vary from primary cells [26,27]. Especially, when used in mono-immune 
cell cultures, as immune cells regulate each other's function. This is why our control experiments were done with LCM.

In the past years, it seemed intriguing that circulating factors might be used to predict the success of fracture healing. Zimmermann et al. proposed that an insufficient increase and a rapid decline in TGF- $\beta$ after a fracture may predict a non-union [8]. However, its systemic over-representation in case of chronic inflammatory diseases might hamper the fracture healing [36].

Both autocrine and paracrine stimulation by TGF- $\beta$ have been reported to critically regulate attraction, expansion and differentiation of osteoprogenitor cells [12-14], which possess a large variety of high-affinity TGF- $\beta$ receptors [11]. In our experiments, phOBs exposure to monocyte- and macrophage-conditioned media strongly induced the canonical (Smad3-dependent) TGF- $\beta$ signaling, suggesting that these cells secrete active TGF- $\beta$ in order to attract osteoprogenitor cells. From the three TGF- $\beta$ isoforms, TGF- $\beta_{1}$ has been reported to have the strongest chemotactic effect towards osteoblastic cells [15]. Supporting this, gap closure (scratch assay) was accelerated in the presence of rhTGF- $\beta_{1}$. Furthermore, the cell migration towards rhTGF- $\beta_{1}$ (under agar spot assay) was induced. Inhibition of the TGF- $\beta$ signaling with the Alk5 inhibitor (SB431542) significantly reduced phOBs' migration, suggesting that activation of the canonical TGF- $\beta$ signaling is pivotal for the observed effects. This does not only hold for cell migration. There are other reports, showing that proliferation and collagen expression of osteoprogenitor cells are also dependent on the canonical (often Smad3-dependent) TGF- $\beta$ signaling [11,12].

In the next step, we identified a rhTGF- $\beta_{1}$-dependent up-regulation of NOX4. A unique feature of NOX4 is that its activity is reported to directly correlate with its expression levels [18]. Thus, it is not surprising that the rhTGF- $\beta_{1}$-dependent up-regulation of NOX4 was confirmed on the protein level. Interestingly, NOX4 was shown to be strongly expressed in migrating vascular smooth muscle cells. In these cells, Poldip2 is associated with the subunit, p22phox, to activate NOX4 [16,17]. However, no possible stimulatory effects of TGF- $\beta$ have been investigated. However, there are other reports, showing that TGF- $\beta$ might induce NOX4 expression. For example, in cardiac fibroblasts, hepatocytes, airway, and artery smooth muscle cells, the TGF- $\beta$-dependent up-regulation of NOX4 seemed to be Smad3- and NFkB-dependent [18,21,22].

The NADPH oxidases generate ROS (mainly $\mathrm{O}_{2}{ }^{-}$and $\mathrm{H}_{2} \mathrm{O}_{2}$ ) as a side product [18], which in turn are thought to regulate diverse cellular responses [20]. Upon addition of NADPH, we saw a significant increase in ROS production in the rhTGF- $\beta_{1}$-treated phOBs, pointing towards an increased NOX activity. Co-incubation with the NOX4 inhibitor, Apocynin, reduced ROS formation in these cells [37], which might be partially attributed to the radical scavenging characteristic of Apocynin [38]. Furthermore, ROS production itself might regulate the TGF- $\beta$-dependent effects via expression of heat shock proteins, e.g., HSP22, which in turn affected migration of osteogenic MC3T3-E1 cells [39]. Blocking NOX4 activity/ROS formation delayed the gap closure (scratch assay) in the presence of rhTGF- $\beta_{1}$, as well as the cell migration towards rhTGF- $\beta_{1}$ (under agar spot assay). In migrating vascular smooth muscle cell, induction of NOX4 and associated ROS accumulation lead to an activation of FAK [23]. This is also seen in rhTGF- $\beta_{1}$ treated phOBs in our study. Blocking both TGF- $\beta$ signaling (SB431542) and NOX4 activity/ROS formation (Apocynin) effectively blocked FAK phosphorylation (Y397). Similar to the inhibition of TGF- $\beta$ signaling (SB431542) and NOX4 activity (Apocynin), blocking FAK phosphorylation (FAKi14) delayed the gap closure (scratch assay) in the presence of rhTGF- $\beta_{1}$ (and LCM). Furthermore, the cell migration towards rhTGF- $\beta_{1}$ (under agar spot assay) was delayed when FAK phosphorylation was inhibited.

So far, cell migration was often investigated in cancerous cell lines, e.g., lung and breast epithelial (cancer) cells. In these cells, this phenomenon was reported to be dependent on p53 status [24], which can be influenced by histone modifications [25]. However, this might be peculiar for cancer cells. Regarding bone, there are reports showing a direct correlation between NADPH oxidase activity and expansion of osteolytic bone metastases [40]. In the 3 osteosarcoma-derived osteogenic cell lines (MG-63, Cal-72, and SaOs-2) investigated here, the NOX4 expression levels correlated well with the 
cells migration capacity. Similarly, overproduction of ROS by NOX4 might also negatively affect bone by favoring osteoclastogenesis. NOX4 knockout mice show an increased bone mineral density, due to a reduced osteoclastogenesis [41]. However, this does not represent the situation after a fracture. In the fracture hematoma, it is feasible that hypoxic conditions and release/activation of TGF- $\beta$, both reported to stimulate NOX4 expression [18-22], might induce a transient increase in NOX4 that is needed to attract osteoprogenitor cells to the fracture site.

\section{Materials and Methods}

\subsection{Ethics Statement}

All human studies were performed in accordance with the Declaration of Helsinki (1964) in its latest amendment. Immature phOBs were isolated from bone tissue explants of the patients that received total joint replacement in our level 1 trauma center. According to the corresponding ethical vote (364/2012BO2 accepted 07.08.2012 from the "Ethik-Kommission an der Medizinischen Fakultät der Eberhard-Karls-Universität und am Universitätsklinikum Tübingen"), tissue was only harvested after medical consultation and written patient consent. The performed surgery was not altered due to the harvesting procedure. Tissues from (potential) tumor patients, patients with viral or bacterial infections and patients unable to give their consent were excluded from this study.

\subsection{Isolation, Expansion, and Osteogenic Differentiation of phOBs}

Bone tissue was disintegrated mechanically into millimeter-sized pieces. After washing 3 to 4 times with phosphate buffered saline (PBS), the pieces were incubated in a $0.7 \%$ collagenase II solution (Biochrom, Berlin, Germany) for about $1 \mathrm{~h}$ at $37^{\circ} \mathrm{C}$. Cancellous bone pieces were washed with PBS, and released phOBs were transferred to cell culture flasks in the culture medium (MEM/Ham's F12, 10\% FCS, $100 \mathrm{U} / \mathrm{mL}$ penicillin, $100 \mu \mathrm{g} / \mathrm{mL}$ streptomycin, $50 \mu \mathrm{M}$ L-ascorbate-2-phosphate, $50 \mu \mathrm{M}$ $\beta$-glycerol phosphate) for expansion. The medium was changed every 3-4 days. For the experiments, the cells (passage 3) were seeded at a density of $20,000 \mathrm{cells} / \mathrm{cm}^{2}$ in the culture medium. After 3 days, the culture medium was replaced by osteogenic differentiation medium (MEM/Ham's F12, 1\% FCS, $100 \mathrm{U} / \mathrm{mL}$ penicillin, $100 \mu \mathrm{g} / \mathrm{mL}$ streptomycin, $200 \mu \mathrm{M}$ L-ascorbate-2-phosphate, $5 \mathrm{mM} \beta$-glycerol phosphate, $25 \mathrm{mM}$ HEPES, $1.5 \mathrm{mM} \mathrm{CaCl}_{2}, 100 \mathrm{nM}$ dexamethasone) $\pm 5 \mathrm{ng} / \mathrm{mL}$ recombinant human TGF- $\beta_{1}$ (rhTGF- $\beta_{1}$ ) (Peprotech, Hamburg, Germany) [13].

\subsection{Generation of Immune Cell Conditioned Medium}

THP-1 cells (ACC-16) and HL-60 cells (ACC-3) were obtained from DSMZ (Leibniz-InstitutDeutsche Sammlung für Mikroorganismen und Zellkulturen $\mathrm{GmbH}$ ). Both (suspension) cell lines were expanded in a RPMI1640 medium (5\% FCS, $100 \mathrm{U} / \mathrm{mL}$ penicillin, $100 \mu \mathrm{g} / \mathrm{mL}$ streptomycin). Leucocytes were isolated by density gradient centrifugation (Percoll ${ }^{\mathrm{TM}}$ with a density of $1.08 \mathrm{~g} / \mathrm{mL}$ ). The conditioned medium was generated with $4 \times 10^{5}$ cells $/ \mathrm{mL}$. After $48 \mathrm{~h}$, cells were removed from the conditioned medium by centrifugation (first $600 \times g$ for $5 \mathrm{~min}$, then $1000 \times g$ for $5 \mathrm{~min}$ ). Conditioned media were stored at $-80^{\circ} \mathrm{C}$ until use. Cells were treated as follows:

- monocytes are represented by THP-1 cells in suspension culture (culture medium) [26]

- macrophages are represented by adherent THP-1 cells (stimulation with 200 nM PMA) [26]

- granulocytes are represented by HL-60 cells cultured in 1.25\% DMSO (1 week) [27]

Morphologic changes have been confirmed by fluorescent microscopy for Calcein-AM (viable stain present in the cells' cytosols) and Hoechst 33342 (nuclear stain) or Pappenheim staining.

\subsection{Cell Migration Assays}

Migration of cells was determined with either a "scratch assay" or an "under agar spot assay": 
For the "scratch assay", cells were plated with high density in 48-well plates. When confluency was reached, the cell layer was mechanically wounded with a pipet tip. Immediately after setting the wound, the medium was changed to remove detached cells and start stimulation $( \pm 5 \mathrm{ng} / \mathrm{mL}$ rhTGF- $\beta_{1} / \pm$ inhibitors). The "scratches" were documented by taking microscopic images directly after wounding $(0 \mathrm{~h})$ and after $40 \mathrm{~h}$. Wound closure was quantified with the ImageJ software (Version 1.5, $\mathrm{NIH}$, Bethesda, MD, USA) by using the following formula: $100-\left(\operatorname{area}_{40 \mathrm{~h}} \times 100 / \mathrm{area}_{0 \mathrm{~h}}\right)$.

For the "under agar spot assay", low melting agarose (0.5\%) was liquefied in PBS (a negative control) with $\pm 1 \mathrm{ng} / \mu \mathrm{L}$ rhTGF- $\beta_{1}$ (positive control), of which $7 \mu \mathrm{L}$ drops were placed in 24-well plates and left to solidify at $4{ }^{\circ} \mathrm{C}$. After $3 \mathrm{~h}$, phOBs were plated around the agarose spots at a high density in the culture medium \pm inhibitors. After $48 \mathrm{~h}$, cell migration was documented by taking microscopic images. Cell migration was quantified with the ImageJ software by using the following formula: $\left(\right.$ area $_{\text {spot }}-$ area $\left._{\text {inviding cells }}\right) \times 100 /$ area $_{\text {spot }}$.

\subsection{Transient Cell Infections and Reporter Gene Assay}

Cells were infected with the Smad3/4 reporter adenovirus (Ad5-CAGA9-MLP-Luc/provided by Prof. P. ten Dijke), as described before [36]. Upon binding of phosphorylated Smad3/4, luciferase is expressed in the cytoplasm of the cells. Cell lysates and luciferase activity measurement was done according to the manufacturer's instructions, using the Rapid detection of Firefly Luciferase Assay System (Promega, Madison, WI, USA) and normalized to total protein content. Infection efficiency was shown to be $>90 \%$ by fluorescent microscopy of cells infected with Ad5-GFP (green fluorescent protein) (24h).

\subsection{Gene Expression Analysis}

Trifast reagent (Peqlab, Erlangen, Germany) was used to isolate total RNA. Expression of oxidative stress related genes was screened with the $\mathrm{RT}^{2}$ Profiler PCR Array human oxidative stress plus (Qiagen, Hilden, Germany). The array was performed with 2 pools (each $N=8$ donors) of RNA samples to minimize the donor dependent variations. RNA purification, cDNA synthesis and the array itself were performed as indicated by the manufacturer, using the advised products from Qiagen. Semi-quantitative RT-PCR was done to confirm gene expression changes of the individual samples. RT-PCR was performed with the KAPA2G Fast Ready Mix from Peqlab, using the primers for NOX4 (NM_016931.4) forward: 5'-CGGGCTTCCACTCAGTCTTT-3' and reverse: 5'-TCCTAGCCCCAACATCTGGT-3' and GAPDH (glycerinaldehyd-3-phosphat-dehydrogenase/ NM_002046.4) forward: 5'-GTCAGTGGTGGACCTGACCT-3' and reverse: 5'-AGGGGTCTACAT GGCAACTG-3'. PCR products, separated by agarose gel electrophoresis, were visualized by ethidium bromide (geldoc/INTAS, Göttingen, Germany). Each sample was loaded twice $(n=2)$ to minimize loading differences. Signal intensities were quantified using the ImageJ software [42].

\subsection{Western Blot Analysis}

Cells were lysed in a freshly prepared ice-cold RIPA buffer. Samples with $30 \mu \mathrm{g}$ total protein, quantified by micro Lowry, were separated by SDS PAGE and transferred onto nitrocellulose membranes. Membranes were blocked with 5\% BSA in TBS-T for $1 \mathrm{~h}$ at ambient temperature, followed by overnight incubation at $+4{ }^{\circ} \mathrm{C}$ with primary antibodies for NOX4 (sc-55142/Santa Cruz Biotechnology, Heidelberg, Germany), phospho-FAK (Y397) (ab4803/abcam, Cambridge, UK), phospho-Smad3 (9520, Cell Signaling Technology, Frankfurt, Germany) diluted 1:1000 in TBS-T. The next day, membranes were incubated with the corresponding peroxidase-labeled secondary antibodies (1:5000 in TBS-T/Santa Cruz Biotechnology) for $2 \mathrm{~h}$ at ambient temperature. GAPDH (G9545, Sigma-Aldrich, Munich, Germany) was used for normalization. Chemiluminescent signals were detected by a CCD camera (INTAS) and quantified with the ImageJ software. 


\subsection{Determination of ROS Levels}

Intracellular ROS levels were determined with the $2^{\prime}, 7^{\prime}$-dichlorofluorescein-diacetate (DCFH-DA) assay. Briefly, phOBs were incubated with $10 \mu \mathrm{M}$ DCFH-DA for $25 \mathrm{~min}$ at $37^{\circ} \mathrm{C}$. After being washed twice with PBS, cells were stimulated with $0.001 \% \mathrm{H}_{2} \mathrm{O}_{2}$ as a positive control. After $0,5,10$ and $15 \mathrm{~min}$, the increase in fluorescence $(\mathrm{ex} / \mathrm{em}=485 / 520 \mathrm{~nm}$ ) was detected using a plate reader, representing levels of $\bullet \mathrm{O}_{2}{ }^{-}, \mathrm{H}_{2} \mathrm{O}_{2}, \mathrm{HO} \bullet$ and $\mathrm{ONOO}^{-}$[43].

\subsection{Culture of Osteogenic Cells Lines}

The osteogenic cell lines-MG-63, Cal-72, and SaOs-2 (obtained from the DSMZ)—were all cultured in the RPMI 1640 medium ( $5 \%$ FCS, $100 \mathrm{U} / \mathrm{mL}$ penicillin, $100 \mu \mathrm{g} / \mathrm{mL}$ streptomycin) for no longer than 15 passages.

\subsection{Statistical Analysis}

Results were represented in either bar diagrams (mean $\pm 95 \%$ confidence interval) or box blots (Box and Whiskers-Tukey to visualize outliers). The number of biological (donors $/ \mathrm{N}$ ) and technical replicates $(n)$ was given in the figure legends. Comparison of multiple groups was done using the Kruskal-Wallis H-test followed by the Dunn's multiple comparison test. The Mann-Whitney U-test (2-sided) was used to compare two single groups with each other. Statistical analysis was performed using the GraphPad Prism Software (Version 5, El Camino Real, CA, USA). $p<0.05$ at an $\alpha=0.05$ was taken as a minimum level of significance.

\subsection{Data Availability}

The datasets generated and analyzed during this study are available from the corresponding author upon reasonable request.

\section{Conclusions}

In conclusion, our data suggested that monocytic- and macrophage-like cells, but not granulocytic cells, induced phOBs migration in a TGF- $\beta$ dependent manner. As key regulators, TGF- $\beta$-dependent induction of NOX4 was identified. The NOX4-induced accumulation of ROS resulted in activation of FAK. Blocking each single step inhibited migration of phOBs, emphasizing their regulatory roles. Knowledge of these mechanisms might help to develop novel therapeutic approaches to supporting the induction of fracture healing.

Author Contributions: Conception, S.E. and A.K.N.; Methodology, S.E. and C.L.; Investigations, S.E., C.L. D.B., S.B., R.H.A.-W., and L.F.; Formal Analysis, S.E. and C.L.; Resources, A.K.N., P.M.D.Z. and F.S.; Writing-Original Draft Preparation, S.E. and C.L.; Writing-Review \& Editing, D.B., S.B., R.H.A.-W., P.M.D.Z., L.F., A.K.N., and F.S.; Visualization, S.E.; Supervision, S.E. and A.K.N.

Funding: This work has been partially supported by the intramural funding of the University of Tübingen (Fortüne Junior 2174-0-0) and the Deutsche Forschungsgemeinschaft (EH471/2).

Acknowledgments: Part of this work has been performed by D.B. and S.B. for their medical dissertation. We acknowledge support from the Deutsche Forschungsgemeinschaft and Open Access Publishing Fund of University of Tübingen.

Conflicts of Interest: The authors declare no conflicts of interest.

\section{Abbreviations}

95\% C.I. 95\% confidence interval

DMSO dimethyl sulfoxide

FAK focal adhesion kinase

NADPH nicotinamide adenine dinucleotide phosphate

NOX4 nicotinamide adenine dinucleotide phosphate (NADPH) oxidase 4

phOBs primary human osteoblasts 


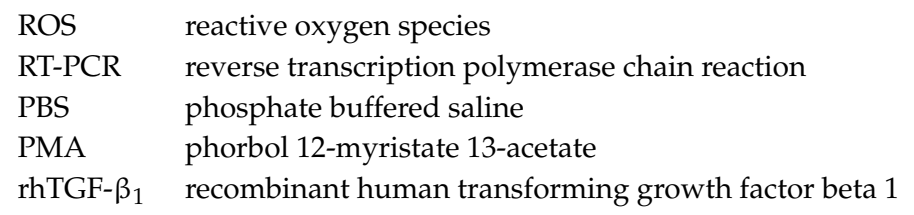

\section{References}

1. Zura, R.; Xiong, Z.; Einhorn, T.; Watson, J.T.; Ostrum, R.F.; Prayson, M.J.; Della Rocca, G.J.; Mehta, S.; McKinley, T.; Wang, Z.; et al. Epidemiology of fracture nonunion in 18 human bones. JAMA Surg. 2016, 151, e162775. [CrossRef] [PubMed]

2. Hak, D.J.; Fitzpatrick, D.; Bishop, J.A.; Marsh, J.L.; Tilp, S.; Schnettler, R.; Simpson, H.; Alt, V. Delayed union and nonunions: Epidemiology, clinical issues, and financial aspects. Injury 2014, 45 (Suppl. S2), S3-S7. [CrossRef] [PubMed]

3. Schmidt-Bleek, K.; Schell, H.; Schulz, N.; Hoff, P.; Perka, C.; Buttgereit, F.; Volk, H.D.; Lienau, J.; Duda, G.N. Inflammatory phase of bone healing initiates the regenerative healing cascade. Cell Tissue Res. 2012, 347, 567-573. [CrossRef] [PubMed]

4. Schmidt-Bleek, K.; Petersen, A.; Dienelt, A.; Schwarz, C.; Duda, G.N. Initiation and early control of tissue regeneration-Bone healing as a model system for tissue regeneration. Expert Opin. Biol. Ther. 2014, 14, 247-259. [CrossRef] [PubMed]

5. Schell, H.; Duda, G.N.; Peters, A.; Tsitsilonis, S.; Johnson, K.A.; Schmidt-Bleek, K. The haematoma and its role in bone healing. J. Exp. Orthop. 2017, 4, 5. [CrossRef] [PubMed]

6. Li, M.O.; Wan, Y.Y.; Sanjabi, S.; Robertson, A.K.; Flavell, R.A. Transforming growth factor-beta regulation of immune responses. Ann. Rev. Immunol. 2006, 24, 99-146. [CrossRef] [PubMed]

7. Kasagi, S.; Chen, W. TGF-beta1 on osteoimmunology and the bone component cells. Cell Biosci. $2013,3,4$. [CrossRef] [PubMed]

8. Zimmermann, G.; Henle, P.; Kusswetter, M.; Moghaddam, A.; Wentzensen, A.; Richter, W.; Weiss, S. TGF-beta1 as a marker of delayed fracture healing. Bone 2005, 36, 779-785. [CrossRef] [PubMed]

9. Bonewald, L.F.; Dallas, S.L. Role of active and latent transforming growth factor beta in bone formation. J. Cell. Biochem. 1994, 55, 350-357. [CrossRef] [PubMed]

10. Erlebacher, A.; Filvaroff, E.H.; Ye, J.Q.; Derynck, R. Osteoblastic responses to TGF-beta during bone remodeling. Mol. Biol. Cell 1998, 9, 1903-1918. [CrossRef] [PubMed]

11. Robey, P.G.; Young, M.F.; Flanders, K.C.; Roche, N.S.; Kondaiah, P.; Reddi, A.H.; Termine, J.D.; Sporn, M.B.; Roberts, A.B. Osteoblasts synthesize and respond to transforming growth factor-type beta (TGF-beta) in vitro. J. Cell Biol. 1987, 105, 457-463. [CrossRef] [PubMed]

12. Derynck, R.; Akhurst, R.J. Differentiation plasticity regulated by TGF-beta family proteins in development and disease. Nat. Cell Biol. 2007, 9, 1000-1004. [CrossRef] [PubMed]

13. Ehnert, S.; Sreekumar, V.; Aspera-Werz, R.H.; Sajadian, S.O.; Wintermeyer, E.; Sandmann, G.H.; Bahrs, C.; Hengstler, J.G.; Godoy, P.; Nussler, A.K. TGF-beta1 impairs mechanosensation of human osteoblasts via hdac6-mediated shortening and distortion of primary cilia. J. Mol. Med. 2017, 95, 653-663. [CrossRef] [PubMed]

14. Ehnert, S.; Zhao, J.; Pscherer, S.; Freude, T.; Dooley, S.; Kolk, A.; Stockle, U.; Nussler, A.K.; Hube, R. Transforming growth factor beta1 inhibits bone morphogenic protein (BMP)-2 and BMP-7 signaling via upregulation of ski-related novel protein $\mathrm{n}(\mathrm{SnoN})$ : Possible mechanism for the failure of bmp therapy? BMC Med. 2012, 10, 101. [CrossRef] [PubMed]

15. Pfeilschifter, J.; Wolf, O.; Naumann, A.; Minne, H.W.; Mundy, G.R.; Ziegler, R. Chemotactic response of osteoblastlike cells to transforming growth factor beta. J. Bone Min. Res. 1990, 5, 825-830. [CrossRef] [PubMed]

16. Lyle, A.N.; Deshpande, N.N.; Taniyama, Y.; Seidel-Rogol, B.; Pounkova, L.; Du, P.; Papaharalambus, C.; Lassegue, B.; Griendling, K.K. Poldip2, a novel regulator of NOX4 and cytoskeletal integrity in vascular smooth muscle cells. Circ. Res. 2009, 105, 249-259. [CrossRef] [PubMed]

17. Miller, F.J., Jr. Nadph oxidase 4: Walking the walk with Poldip2. Circ. Res. 2009, 105, 209-210. [CrossRef] [PubMed] 
18. Katsuyama, M. NOX/nadph oxidase, the superoxide-generating enzyme: Its transcriptional regulation and physiological roles. J. Pharmacol. Sci. 2010, 114, 134-146. [CrossRef] [PubMed]

19. Diebold, I.; Petry, A.; Hess, J.; Gorlach, A. The nadph oxidase subunit NOX4 is a new target gene of the hypoxia-inducible factor-1. Mol. Biol. Cell 2010, 21, 2087-2096. [CrossRef] [PubMed]

20. Pendyala, S.; Gorshkova, I.A.; Usatyuk, P.V.; He, D.; Pennathur, A.; Lambeth, J.D.; Thannickal, V.J.; Natarajan, V. Role of NOX4 and NOX2 in hyperoxia-induced reactive oxygen species generation and migration of human lung endothelial cells. Antioxid. Redox Signal. 2009, 11, 747-764. [CrossRef] [PubMed]

21. Sturrock, A.; Cahill, B.; Norman, K.; Huecksteadt, T.P.; Hill, K.; Sanders, K.; Karwande, S.V.; Stringham, J.C.; Bull, D.A.; Gleich, M.; et al. Transforming growth factor-beta1 induces NOX4 NAD(P)H oxidase and reactive oxygen species-dependent proliferation in human pulmonary artery smooth muscle cells. Am. J. Physiol. Lung Cell. Mol. Physiol. 2006, 290, L661-L673. [CrossRef] [PubMed]

22. Murillo, M.M.; Carmona-Cuenca, I.; Del Castillo, G.; Ortiz, C.; Roncero, C.; Sanchez, A.; Fernandez, M.; Fabregat, I. Activation of nadph oxidase by transforming growth factor-beta in hepatocytes mediates up-regulation of epidermal growth factor receptor ligands through a nuclear factor-kappab-dependent mechanism. Biochem. J. 2007, 405, 251-259. [CrossRef] [PubMed]

23. Datla, S.R.; McGrail, D.J.; Vukelic, S.; Huff, L.P.; Lyle, A.N.; Pounkova, L.; Lee, M.; Seidel-Rogol, B.; Khalil, M.K.; Hilenski, L.L.; et al. Poldip2 controls vascular smooth muscle cell migration by regulating focal adhesion turnover and force polarization. Am. J. Physiol. Heart Circ. Physiol. 2014, 307, H945-H957. [CrossRef] [PubMed]

24. Boudreau, H.E.; Casterline, B.W.; Burke, D.J.; Leto, T.L. Wild-type and mutant p53 differentially regulate nadph oxidase 4 in TGF-beta-mediated migration of human lung and breast epithelial cells. Br. J. Cancer 2014, 110, 2569-2582. [CrossRef] [PubMed]

25. Boudreau, H.E.; Ma, W.F.; Korzeniowska, A.; Park, J.J.; Bhagwat, M.A.; Leto, T.L. Histone modifications affect differential regulation of TGF-beta- induced nadph oxidase 4 (NOX4) by wild-type and mutant p53. Oncotarget 2017, 8, 44379-44397. [CrossRef] [PubMed]

26. Daigneault, M.; Preston, J.A.; Marriott, H.M.; Whyte, M.K.; Dockrell, D.H. The identification of markers of macrophage differentiation in PMA-stimulated THP-1 cells and monocyte-derived macrophages. PLoS ONE 2010, 5, e8668. [CrossRef] [PubMed]

27. Collins, S.J.; Ruscetti, F.W.; Gallagher, R.E.; Gallo, R.C. Terminal differentiation of human promyelocytic leukemia cells induced by dimethyl sulfoxide and other polar compounds. Proc. Natl. Acad. Sci. USA 1978, 75, 2458-2462. [CrossRef] [PubMed]

28. Boudreau, H.E.; Casterline, B.W.; Rada, B.; Korzeniowska, A.; Leto, T.L. NOX4 involvement in TGF-beta and SMAD3-driven induction of the epithelial-to-mesenchymal transition and migration of breast epithelial cells. Free Radical Biol. Med. 2012, 53, 1489-1499. [CrossRef] [PubMed]

29. Julier, Z.; Park, A.J.; Briquez, P.S.; Martino, M.M. Promoting tissue regeneration by modulating the immune system. Acta Biomater. 2017, 53, 13-28. [CrossRef] [PubMed]

30. Gibon, E.; Lu, L.Y.; Nathan, K.; Goodman, S.B. Inflammation, ageing, and bone regeneration. J. Orthop. Transl. 2017, 10, 28-35. [CrossRef] [PubMed]

31. Mizuno, K.; Mineo, K.; Tachibana, T.; Sumi, M.; Matsubara, T.; Hirohata, K. The osteogenetic potential of fracture haematoma. Subperiosteal and intramuscular transplantation of the haematoma. J. Bone Jt. Surg. Br. 1990, 72, 822-829. [CrossRef]

32. Schmidt-Bleek, K.; Schell, H.; Kolar, P.; Pfaff, M.; Perka, C.; Buttgereit, F.; Duda, G.; Lienau, J. Cellular composition of the initial fracture hematoma compared to a muscle hematoma: A study in sheep. J. Orthop. Res. 2009, 27, 1147-1151. [CrossRef] [PubMed]

33. Kovtun, A.; Bergdolt, S.; Wiegner, R.; Radermacher, P.; Huber-Lang, M.; Ignatius, A. The crucial role of neutrophil granulocytes in bone fracture healing. Eur. Cell Mater. 2016, 32, 152-162. [CrossRef] [PubMed]

34. Soehnlein, O.; Lindbom, L.; Weber, C. Mechanisms underlying neutrophil-mediated monocyte recruitment. Blood 2009, 114, 4613-4623. [CrossRef] [PubMed]

35. Claes, L.; Recknagel, S.; Ignatius, A. Fracture healing under healthy and inflammatory conditions. Nat. Rev. Rheumatol. 2012, 8, 133-143. [CrossRef] [PubMed]

36. Ehnert, S.; Baur, J.; Schmitt, A.; Neumaier, M.; Lucke, M.; Dooley, S.; Vester, H.; Wildemann, B.; Stockle, U.; Nussler, A.K. TGF-beta1 as possible link between loss of bone mineral density and chronic inflammation. PLoS ONE 2010, 5, e14073. [CrossRef] [PubMed] 
37. Altenhofer, S.; Radermacher, K.A.; Kleikers, P.W.; Wingler, K.; Schmidt, H.H. Evolution of nadph oxidase inhibitors: Selectivity and mechanisms for target engagement. Antioxid. Redox Signal. 2015, 23, 406-427. [CrossRef] [PubMed]

38. Heumuller, S.; Wind, S.; Barbosa-Sicard, E.; Schmidt, H.H.; Busse, R.; Schroder, K.; Brandes, R.P. Apocynin is not an inhibitor of vascular nadph oxidases but an antioxidant. Hypertension 2008, 51, 211-217. [CrossRef] [PubMed]

39. Yamamoto, N.; Tokuda, H.; Kuroyanagi, G.; Kainuma, S.; Matsushima-Nishiwaki, R.; Fujita, K.; Kozawa, O.; Otsuka, T. Heat shock protein 22 (HSPB8) limits TGF-beta-stimulated migration of osteoblasts. Mol. Cell. Endocrinol. 2016, 436, 1-9. [CrossRef] [PubMed]

40. McCarty, M.F.; DiNicolantonio, J. Suppression of nadph oxidase activity may slow the expansion of osteolytic bone metastases. Healthcare 2016, 4, 60. [CrossRef] [PubMed]

41. Goettsch, C.; Babelova, A.; Trummer, O.; Erben, R.G.; Rauner, M.; Rammelt, S.; Weissmann, N.; Weinberger, V.; Benkhoff, S.; Kampschulte, M.; et al. Nadph oxidase 4 limits bone mass by promoting osteoclastogenesis. J. Clin. Investig. 2013, 123, 4731-4738. [CrossRef] [PubMed]

42. Ehnert, S.; Fentz, A.K.; Schreiner, A.; Birk, J.; Wilbrand, B.; Ziegler, P.; Reumann, M.K.; Wang, H.; Falldorf, K.; Nussler, A.K. Extremely low frequency pulsed electromagnetic fields cause antioxidative defense mechanisms in human osteoblasts via induction of ${ }^{*} \mathrm{O}_{2}(-)$ and $\mathrm{H}_{2} \mathrm{O}_{2}$. Sci. Rep. 2017, 7, 14544. [CrossRef] [PubMed]

43. Kalyanaraman, B.; Darley-Usmar, V.; Davies, K.J.; Dennery, P.A.; Forman, H.J.; Grisham, M.B.; Mann, G.E.; Moore, K.; Roberts, L.J., 2nd; Ischiropoulos, H. Measuring reactive oxygen and nitrogen species with fluorescent probes: Challenges and limitations. Free Radical Biol. Med. 2012, 52, 1-6. [CrossRef] [PubMed]

(C) 2018 by the authors. Licensee MDPI, Basel, Switzerland. This article is an open access article distributed under the terms and conditions of the Creative Commons Attribution (CC BY) license (http:/ / creativecommons.org/licenses/by/4.0/). 